\title{
Plasma nicotine levels after cigarette smoking and chewing nicotine gum
}

\author{
M A H RUSSELL, C FEYERABEND, P V COLE
}

British Medical fournal, 1976, 1, 1043-1046

\begin{abstract}
Summary
Plasma nicotine levels were measured over seven hours of smoking cigarettes ( $1.2 \mathrm{mg}$ nicotine) in a single subject under standardised conditions, and were compared with the levels obtained from chewing-gum containing either $2 \mathrm{mg}$ or $4 \mathrm{mg}$ nicotine. Levels comparable to those resulting from smoking were not obtained with the 2-mg gum, but peak levels on the $4-\mathrm{mg}$ gum averaged $40 \cdot 1 \mathrm{ng} / \mathrm{ml}$ from the third gum onwards compared with $49.2 \mathrm{ng} / \mathrm{ml}$ after cigarettes. Nicotine was absorbed much more slowly from the gum than from cigarettes. It took 15-30 minutes for the 4-mg gum to raise the plasma nicotine by an average of $11.9 \mathrm{ng} / \mathrm{ml}$ compared with an average increase of $27.8 \mathrm{ng} / \mathrm{ml}$ within two minutes of completing each cigarette. In a sample of 15 smokers attending a withdrawal clinic the average plasma nicotine concentration while taking 2-mg nicotine chewing-gum was only $10 \cdot 8 \mathrm{ng} / \mathrm{ml}$ compared with $30.4 \mathrm{ng} / \mathrm{ml}$ two minutes after smoking a cigarette. Although plasma nicotine levels equivalent to those following cigarette smoking may be obtained by chewing at least 10 pieces of $4-\mathrm{mg}$ nicotine gum daily, the slower rate of absorption may limit its therapeutic value as a substitute for cigarette smoking.
\end{abstract}

\section{Introduction}

No really effective treatment for dependent tobacco smokers has been found. ${ }^{12}$ So many smokers need help that to be useful on a large scale a treatment, besides being effective, would have to be self-administered or require only a minimum of rime from a doctor or therapist. One approach has been the search for a satisfactory drug for temporary use during withdrawal. Lobeline and tranquillisers are still used, although they are no more effective than a placebo. ${ }^{12}$ Ingestion of nicotine capsules has very little inhibitory effect on smoking, ${ }^{3}$ which is not surprising since most of the nicotine absorbed through the gut is metabolised during its first passage through the liver before ever reaching the general circulation. ${ }^{4}$ Although cigarette craving ${ }^{5}$ and consumption $^{8}$ are both reduced by nicotine injections, the redistribution, metabolism, and excretion of nicotine is so rapid that too many injections would be needed for this to be a practical form of substitution therapy. This finding does, however, suggest that some form of alternative nicotine dosage might be an effective temporary substitute for smoking and as such a useful aid to cigarette withdrawal.

\footnotetext{
Addiction Research Unit, Institute of Psychiatry and Maudsley Hospital, London SE5 8AF

M A H RUSSELL, MRCP, senior lecturer and honorary consultant

Poisons Unit, New Cross Hospital, London SE14

C FEYERABEND, BSC, research worker

\begin{tabular}{l} 
Anaesthetic Research Laboratory, St Bartholomew's Hospital, \\
London EC1 \\
P V COLE, FFARCs, consultant anaesthetist \\
\hline
\end{tabular}
}

With this in mind a chewing-gum containing nicotine has been developed in Sweden ${ }^{7}$ and clinical trials there suggest that it may be a useful aid to cigarette withdrawal. ${ }^{8}{ }^{9}$ Besides conducting a clinical trial, ${ }^{10}$ we have studied the plasma nicotine levels obtained from chewing nicotine gum and compared them with levels after smoking cigarettes.

\section{Subjects and methods}

The nicotine chewing-gum was manufactured and supplied by Leo and Co, Helsinborg, Sweden. It was available in two strengths: $4 \mathrm{mg}$ and $2 \mathrm{mg}$ nicotine in each piece of gum. The nicotine is bound to be an ion exchanger that allows it to be released slowly over 20-30 minutes as the gum is chewed, the rate of release being dependent on the vigour and rate of chewing. ${ }^{7}$ Because buccal absorption of nicotine is $\mathrm{pH}$ dependent, the gum contains a buffer which keeps the $\mathrm{pH}$ in the mouth at about 8.5 as the gum is chewed.

\section{SINGLE-SUBJECT STUDY}

Multiple blood samples were taken from a 38-year-old man over six or seven hours on different days while he either smoked cigarettes or chewed $2-\mathrm{mg}$ or $4-\mathrm{mg}$ gum. The subject was a regular cigarette smoker who inhaled and smoked an average of 21 cigarettes a day. His usual brand of filter-tipped cigarettes (tar yield $20 \mathrm{mg}$, nicotine $1.2 \mathrm{mg}$ ) were used in the experiments. Before each day's experiment he refrained from smoking for at least 12 hours. Ammonium chloride was administered to acidify his urine. Blood samples $(5 \mathrm{ml})$ were drawn from a forearm vein via an indwelling cannula at the following times: $9.00,9.07,9.15,9.30,10.00,10.07,10.15,10.30 \mathrm{am}$, and so on for seven hours to a total of twenty-eight samples on one day. After taking the baseline sample at 9.00 am a cigarette was smoked over five minutes. Subsequent cigarettes were smoked on the hour to a total of seven cigarettes over the seven hours of experiment. The timing of the blood samples was therefore just before, and 2, 10, 25, and 55 minutes after completing each of the seven cigarettes. The experiment was repeated with 4-mg nicotine chewing-gum started on the hour and chewed for 30 minutes to a total of seven pieces during the seven-hour experiment. This frequency of blood sampling allowed the peak nicotine levels after cigarette smoking and chewing the 4-mg nicotine gum, to be compared, as well as the minimal or trough levels just before each hourly cigarette or gum. To reduce the amount of blood removed, when studying the 2 -mg nicotine gum blood samples were taken only hourly, on the hour, just before the subject chewed each piece of gum. This enabled us to compare trough levels, but not peak levels, of plasma nicotine. Urine was also collected hourly and the $\mathrm{pH}$ measured immediately. The subject remained ambulant during the experiment. Lunch was taken between 1.30 and $1.50 \mathrm{pm}$. A fuller report including details of the urinary excretion rates of nicotine and the effect on plasma and urine nicotine levels of alkaline and acid control or urine $\mathrm{pH}$ in this one subject is being prepared. ${ }^{11}$

\section{SMOKERS' CLINIC SAMPLE}

Plasma nicotine levels after smoking and after taking 2-mg nicotine chewing-gum were compared in 15 smokers attending the Maudsley Hospital smokers' clinic. Five other smokers were excluded: three had dentures and could not chew the gum adequately, and two did not adhere to the prescribed dose. Venous blood samples were taken two minutes after completing a cigarette during the afternoon of a day spent smoking their usual brand in their usual way. A second sample was taken at roughly the same time of day after they had been taking 2-mg nicotine chewing-gum for at least a week and had stopped smoking. Abstinence from smoking was confirmed by measuring their blood 
carboxyhaemoglobin $(\mathrm{COHb})$ levels. The dose of nicotine gum was 10 pieces a day, the first seven pieces hourly and the remaining three pieces two-hourly, each chewed for at least 30 minutes. The first piece of gum of the day was taken at a time convenient to each subject so that the number of pieces taken by the time the blood was collected varied between subjects, as did the actual time of taking the blood. Nevertheless, for each subject blood samples after smoking and while on the gum were taken at roughly the same time of day. Urine $\mathrm{pH}$ was not controlled in this study.

\section{ANALYSIS}

In both studies blood specimens were centrifuged within two hours and the plasma kept frozen until analysis for nicotine. Blood nicotine was measured by gas chromatography. ${ }^{12}$ Specimens for $\mathrm{COHb}$ (second study only) were refrigerated overnight in capped heparinised syringes and analysed the next day using an IL 182 CO-Oximeter. ${ }^{13}$ Statistical comparisons are shown by $t$ tests. Significance levels were the same when checked by Mann-Whitney $U$ and Wilcoxon tests.

\section{Results}

SINGLE-SUBJECT STUDY

Complete plasma nicotine profiles during seven hours of cigarette smoking and during seven hours on 4-mg nicotine chewing-gum under standardised conditions in the same subject can be seen in fig 1 . These show peak levels after each nicotine dose and troughs just before dosage as well as the actual increases produced by each dose.

Peak levels-The peak plasma nicotine levels after each cigarette were: $35 \cdot 4,40 \cdot 6,46 \cdot 0,51 \cdot 1,46 \cdot 6,48 \cdot 5$, and $54 \cdot 0 \mathrm{ng} / \mathrm{ml}$ (mean $( \pm \mathrm{SE}$ of mean) $46 \cdot 0 \pm 2 \cdot 4 \mathrm{ng} / \mathrm{ml}$ ). These levels were fairly consistent, especially from the third cigarette onwards, when the average was $49.2 \pm 1.5 \mathrm{ng} / \mathrm{ml}$. Excluding the first two gums of the day, the peak levels obtained after each piece of 4-mg gum were: $32 \cdot 7,42 \cdot 1,42 \cdot 7$, 35.3 , and $47.6 \mathrm{ng} / \mathrm{ml}$ (mean $40.1 \pm 2.7 \mathrm{ng} / \mathrm{ml}$ ). This was significantly less than the mean of $49.2 \mathrm{ng} / \mathrm{ml}$ obtained with cigarettes $(t=2.98$; $\mathrm{DF}=8 ; \mathrm{P}<0.02$ )

Increase per dose-Plasma nicotine levels increased sharply after smoking. The increases produced within two minutes of finishing each cigarette were: $30 \cdot 6,26 \cdot 2,30 \cdot 0,26 \cdot 6,22 \cdot 2,27 \cdot 1$, and $31 \cdot 9 \mathrm{ng} / \mathrm{ml}$ (mean $27.8+1.2 \mathrm{ng} / \mathrm{ml}$ ). The maximal increases in plasma nicotine produced by each piece of 4-mg nicotine chewing-gum took 15-30 minutes to develop and were $12 \cdot 8,9 \cdot 6,8 \cdot 3,12 \cdot 4,12 \cdot 8,11 \cdot 7$, and $15 \cdot 7$ $\mathrm{ng} / \mathrm{ml}$ (mean $11.9 \pm 0.9 \mathrm{ng} / \mathrm{ml}$ ). The difference between these two means was more than twofold and was statistically significant $(t=$ 10.3; $\mathrm{P}<0.001$ ).

Trough levels-In contrast with the peak levels, the trough levels obtained with the 4-mg gum were slightly higher than those obtained by smoking (figs 1 and $2 ; t=2.84 ; \mathrm{DF}=9 ; \mathrm{P}<0.02$ ) and very much higher than with the 2 -mg gum (fig 2 ). The trough levels on the $2-\mathrm{mg}$
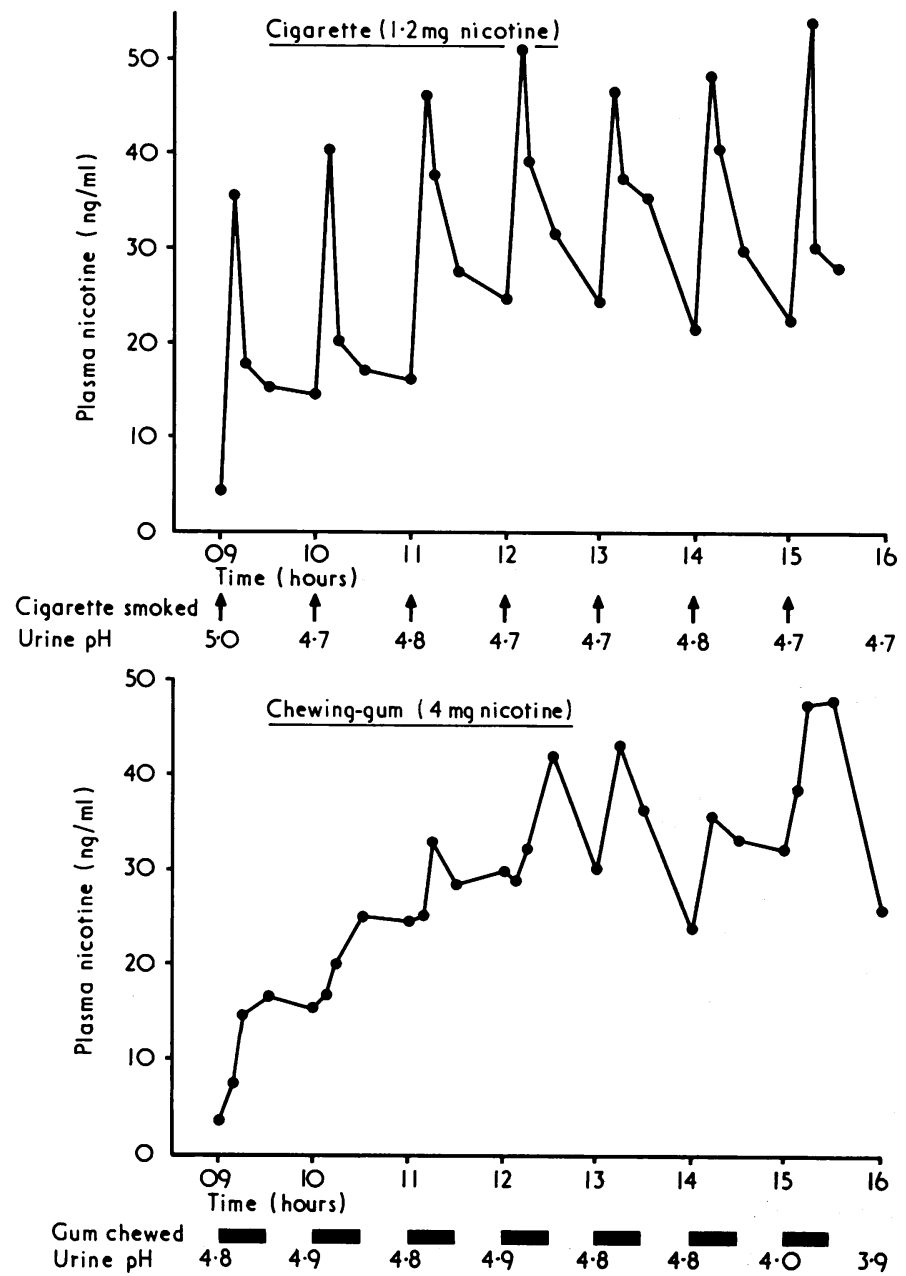

FIG 1 -Plasma nicotine levels while subject smoked one cigarette per hour and while he took nicotine chewing-gum hourly. Urine controlled at acid pH.

gum were also well below those after smoking $(t=6 \cdot 4 ; \mathrm{DF}=9$, $P<0 \cdot 001)$.

\section{SMOKERS' CLINIC SAMPLE}

The data from the clinic sample are shown in the table. The average plasma nicotine level $( \pm S D)$ obtained while on the 2-mg nicotine

Plasma nicotine levels after cigarette smoking and while taking 2-mg nicotine chewing-gum in 15 smokers attending a withdrawal clinic

\begin{tabular}{|c|c|c|c|c|c|c|c|c|c|c|}
\hline \multirow[t]{2}{*}{ Subject } & \multirow[t]{2}{*}{ Age } & \multirow{2}{*}{$\begin{array}{c}\text { Weight } \\
(\mathbf{k g})\end{array}$} & \multicolumn{2}{|c|}{ Usual consumption } & \multicolumn{2}{|c|}{$\begin{array}{l}\text { Blood level during } \\
\text { usual smoking } 2 \text { minutes } \\
\text { after cigarette }\end{array}$} & \multicolumn{2}{|c|}{$\begin{array}{l}\text { Blood levels after } \\
\text { stopping smoking while } \\
\text { taking 2-mg nicotine } \\
\text { gum }\end{array}$} & \multirow{2}{*}{$\begin{array}{c}\text { Time at } \\
\text { which } \\
\text { blood was } \\
\text { taken } \\
\text { (pm) }\end{array}$} & \multirow{2}{*}{$\begin{array}{l}\text { No of gums } \\
\text { taken on day of } \\
\text { blood sampling } \\
\text { and time last } \\
\text { gum was } \\
\text { started }\end{array}$} \\
\hline & & & Cigarettes/day & $\begin{array}{l}\text { Nicotine } \\
\text { yield } \\
(\mathrm{mg})\end{array}$ & $\begin{array}{l}\text { Nicotine } \\
(\mathrm{ng} / \mathrm{ml})\end{array}$ & $\underset{(\%)}{\mathrm{COHb}}$ & $\begin{array}{l}\text { Nicotine } \\
(\mathrm{ng} / \mathrm{ml})\end{array}$ & $\underset{(\%)}{\mathrm{COHb}}$ & & \\
\hline \multicolumn{11}{|c|}{ Women } \\
\hline $\begin{array}{r}1 \\
2 \\
3 \\
4 \\
5 \\
6 \\
7 \\
8 \\
9 \\
10\end{array}$ & $\begin{array}{l}46 \\
40 \\
31 \\
32 \\
33 \\
21 \\
37 \\
30 \\
29 \\
47\end{array}$ & $\begin{array}{l}59 \cdot 9 \\
68 \cdot 5 \\
54 \cdot 4 \\
65 \cdot 3 \\
68 \cdot 5 \\
59 \cdot 4 \\
59 \cdot 0 \\
46 \cdot 7 \\
46 \cdot 7 \\
64 \cdot 9\end{array}$ & $\begin{array}{r}35 \\
40 \\
22 \\
30 \\
30 \\
40 \\
20 \\
22 \\
23 \\
110\end{array}$ & $\begin{array}{l}1.3 \\
0.8 \\
1.4 \\
0.8 \\
1.3 \\
1.3 \\
0.9 \\
1.1 \\
1.2 \\
1.1\end{array}$ & $\begin{array}{l}36 \cdot 2 \\
15 \cdot 5 \\
22 \cdot 3 \\
26 \cdot 5 \\
23 \cdot 0 \\
20 \cdot 0 \\
23 \cdot 5 \\
24 \cdot 6 \\
40 \cdot 7 \\
32 \cdot 7\end{array}$ & $\begin{array}{r}10 \cdot 4 \\
8 \cdot 8 \\
5 \cdot 1 \\
8 \cdot 0 \\
9 \cdot 5 \\
6 \cdot 0 \\
9 \cdot 1 \\
12 \cdot 2 \\
9 \cdot 1 \\
13 \cdot 0\end{array}$ & $\begin{array}{r}12 \cdot 0 \\
7.5 \\
15 \cdot 7 \\
13.7 \\
6 \cdot 4 \\
5 \cdot 4 \\
7 \cdot 3 \\
21 \cdot 8 \\
13.3 \\
18 \cdot 6\end{array}$ & $\begin{array}{l}0.9 \\
0.8 \\
0.5 \\
0.4 \\
1.3 \\
0.3 \\
0.1 \\
0.6 \\
0.7 \\
0.1\end{array}$ & $\begin{array}{l}\mathbf{4} \cdot 02 \\
3 \cdot 40 \\
4 \cdot 47 \\
5 \cdot 47 \\
6 \cdot 45 \\
6 \cdot 15 \\
6 \cdot 35 \\
3 \cdot 47 \\
5 \cdot 57 \\
5 \cdot 20\end{array}$ & $\begin{array}{l}\text { 7, } 3 \mathrm{pm} \\
7,3 \mathrm{pm} \\
7,3.30 \mathrm{pm} \\
6,4.30 \mathrm{pm} \\
9,6 \mathrm{pm} \\
8,6 \mathrm{pm} \\
9,6 \mathrm{pm} \\
5,3 \mathrm{pm} \\
8,4 \mathrm{pm} \\
7,4.30 \mathrm{pm}\end{array}$ \\
\hline Mean \pm SD & $34 \cdot 6 \pm 8 \cdot 0$ & $59 \cdot 4 \pm 8 \cdot 2$ & $37 \cdot 2 \pm 26 \cdot 6$ & $1 \cdot 12 \pm 0 \cdot 22$ & $26 \cdot 5 \pm 7 \cdot 7$ & $9 \cdot 1 \pm 2 \cdot 4$ & $12 \cdot 2 \pm 5 \cdot 5$ & $0.6 \pm 0.4$ & 5.05 & $7 \cdot 3$ \\
\hline \multicolumn{11}{|c|}{ Men } \\
\hline $\begin{array}{l}11 \\
12 \\
13 \\
14 \\
15\end{array}$ & $\begin{array}{l}36 \\
32 \\
57 \\
44 \\
48\end{array}$ & $\begin{array}{l}87 \cdot 1 \\
89 \cdot 4 \\
83 \cdot 5 \\
72 \cdot 6 \\
84 \cdot 8\end{array}$ & $\begin{array}{l}20 \\
35 \\
23 \\
47 \\
55\end{array}$ & $\begin{array}{l}1.4 \\
1.2 \\
1.2 \\
1.8 \\
0.7\end{array}$ & $\begin{array}{l}46 \cdot 0 \\
29 \cdot 1 \\
43 \cdot 7 \\
48 \cdot 4 \\
23 \cdot 8\end{array}$ & $\begin{array}{r}3 \cdot 1 \\
10 \cdot 1 \\
8 \cdot 1 \\
10 \cdot 4 \\
9 \cdot 9\end{array}$ & $\begin{array}{r}10 \cdot 6 \\
6 \cdot 1 \\
8 \cdot 7 \\
7 \cdot 9 \\
6 \cdot 9\end{array}$ & $\begin{array}{l}1 \cdot 1 \\
0.5 \\
0.3 \\
0.8 \\
1.2\end{array}$ & $\begin{array}{l}5 \cdot 37 \\
5 \cdot 06 \\
3 \cdot 12 \\
5 \cdot 40 \\
7 \cdot 12\end{array}$ & $\begin{array}{l}8,5 \mathrm{pm} \\
8,4.15 \mathrm{pm} \\
4,2 \mathrm{pm} \\
8,4 \mathrm{pm} \\
9,7 \mathrm{pm}\end{array}$ \\
\hline Mean \pm SD & $43.4 \pm 9.9$ & $83.5 \pm 6.4$ & $36 \cdot 0 \pm 15 \cdot 1$ & $1 \cdot 26 \pm 0 \cdot 40$ & $38 \cdot 2 \pm 11 \cdot 0$ & $8 \cdot 3 \pm 3 \cdot 1$ & $8 \cdot 0 \pm 1 \cdot 7$ & $0.9 \pm 0.4$ & $5 \cdot 21$ & $7 \cdot 4$ \\
\hline
\end{tabular}




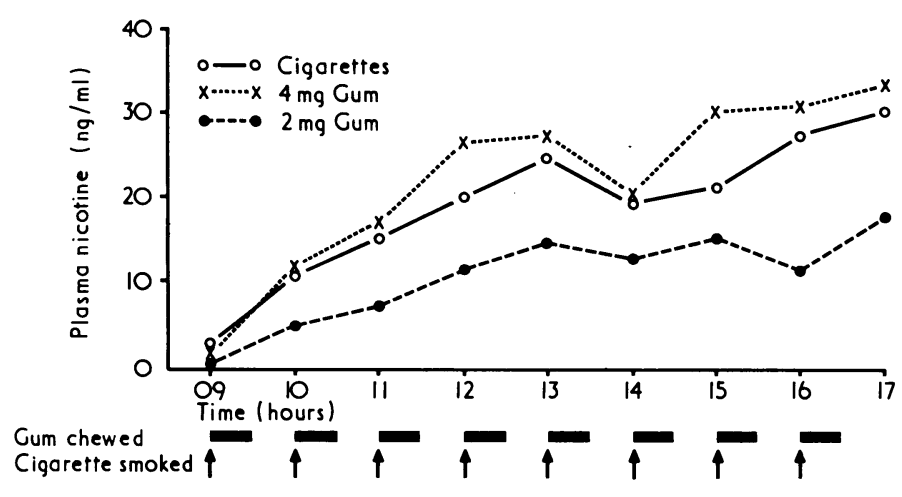

FIG 2-Plasma nicotine trough levels just before smoking or taking nicotine chewing-gum hourly. Urine controlled at acid pH. Values for cigarettes and 4-mg gum are means of values on two days.

chewing-gum was only $10 \cdot 8 \pm 5 \cdot 0 \mathrm{ng} / \mathrm{ml}$ compared with an average peak level of $30.4 \pm 10.3 \mathrm{ng} / \mathrm{ml}$ after smoking $(t=6.8 ; \mathrm{DF}=14 ; \mathrm{P}<$ $0.001)$. The average nicotine level after smoking was higher in men than in women $(38.2 v 26.5 \mathrm{ng} / \mathrm{ml} ; t=2.4 ; \mathrm{P}<0.05)$, but the women had higher levels on the nicotine gum though this difference was not statistically significant $(t=1 \cdot 6 ; \mathrm{DF}=13)$. The average weight of the men was $24 \mathrm{~kg}$ more than that of the women $(t=5.8 ; \mathrm{P}<0.001)$, and there was a negative correlation of -0.56 between the subjects' weight and the plasma nicotine level obtained on the chewing gum $(P<0.05)$. There were no other significant sex differences in the data shown in the table. The trough levels obtained on the $2-\mathrm{mg}$ gum by the subject in the first study (see fig 2) were similar to the average levels of the 15 clinic smokers.

\section{Discussion}

Plasma nicotine levels comparable to those after smoking were obtained with 4-mg nicotine chewing-gum in the single subject study. Apart from the first two gums of the day, peak levels obtained from each piece of gum averaged $40 \cdot 1 \mathrm{ng} / \mathrm{ml}$ and ranged from 32.7 to $47.6 \mathrm{ng} / \mathrm{ml}$. Although this is a little less than the average peak levels of $49.2 \mathrm{ng} / \mathrm{ml}$ obtained after smoking, it compares favourably with the average of $30.4 \mathrm{ng} / \mathrm{ml}$ obtained just after a cigarette by the 15 clinic smokers.

The 2-mg nicotine chewing-gum, on the other hand, did not produce plasma levels equivalent to those obtained by smoking in either the single-subject study or the clinic sample. The average plasma nicotine level of 15 smokers attending the withdrawal clinic was only $10.8 \mathrm{ng} / \mathrm{ml}$ when taking the $2-\mathrm{mg}$ gum compared with $30.4 \mathrm{ng} / \mathrm{ml}$ after cigarette smoking, despite spending up to five hours per day chewing at 10 pieces of gum. This difference is almost threefold and suggests that the 2-mg gum is too small a dose for adequate nicotine substitution.

Nicotine was absorbed much more slowly from the gum than from cigarettes. The peaks occurred 15-30 minutes after the start of chewing (see fig 1) but within two minutes of completing a cigarette. The increase in nicotine level after each cigarette, as opposed to the peak level obtained, averaged $27.8 \mathrm{ng} / \mathrm{ml}$ compared with $11.9 \mathrm{ng} / \mathrm{ml}$ for each piece of $4-\mathrm{mg}$ gum. This indicates that nicotine is absorbed much more rapidly during smoking, especially in view of the fact that the smoking dose of $1.2 \mathrm{mg}$ nicotine per cigarette was only a third of the $3.64-\mathrm{mg}$ nicotine released from the 4-mg gum. ${ }^{7}$ Thus chewing-gum, which releases three times as much nicotine as a cigarette, takes three times as long to produce less than half of the plasma nicotine increase that is obtained from a cigarette.

The consistency in one subject of the plasma nicotine peaks after each cigarette (fig 1) is striking. Both peaks and troughs seem to reach a plateau after the first two cigarettes, and there seems to be little tendency to cumulation of nicotine at a smoking rate of one cigarette per hour in a subject with acidified urine. These findings are in keeping with those of Isaac and
Rand. ${ }^{14}$ They found the plasma half life of nicotine after smoking to be less than 30 minutes, with the decay curves suggesting two components: an initial rapid phase due to distribution followed by a slower phase of excretion and metabolism. In fig 1 the decay between 30 and 60 minutes after starting each cigarette appears to accelerate after midday, and the trough levels in fig 2 show a consistent decrease after $1 \mathrm{pm}$. This seems to be due in part to an increase in urine flow rate at midday as well as to a postprandial effect. These pharmocokinetic aspects are examined and discussed more fully elsewhere. ${ }^{11}$

There were differences in the plasma nicotine levels of the men and the women, both after smoking and while taking 2-mg nicotine chewing-gum. The levels after smoking were higher in the men $(38.2 v 26.5 \mathrm{ng} / \mathrm{ml} ; \mathrm{P}<0.05)$ yet after chewing-gum they were higher in the women $(12.2 v 8.0 \mathrm{ng} / \mathrm{ml}$; not significant $)$. The difference in the levels after the chewing-gum might be explained by the fact that the men were, on avergae, some $24 \mathrm{~kg}$ heavier than the women. The difference after smoking may be due to a tendency for men to inhale more deeply. This explanation is not contradicted by the fact that the $\mathrm{COHb}$ levels of the women were slightly higher than those of the men $(9 \cdot 1 \% v 8.3 \%$; not significant) for we have already shown that the $\mathrm{COHb}$ of women increases more after a single cigarette, ${ }^{15}$ probably because of their lower haemoglobin levels.

Although plasma nicotine levels similar to those after smoking may be built up when taking 4-mg nicotine gum, the pharmacological effects are probably very different. Not only does cigarette smoking produce a more rapid rise and fall of nicotine in the blood and hence the brain, but with each cigarette the nicotine is administered to the brain, and around the body, in a series of intermittent high-nicotine boli after each inhaled puff. ${ }^{4}$ This is not shown in fig 1 since our sampling was limited to before and after each cigarette, and to pick up the post-puff highnicotine boli would necessitate multiple rapid sampling during smoking from arterial rather than venous blood. Multiple intermittent dosage probably produces higher nicotine levels in the brain ${ }^{4}$; it has also been shown to have greater pharmacological effects on the brain compared with continuous administration of the same dose over the same period of time. ${ }^{16}$ The intermittent puff-by-puff high-nicotine bolus that enters the brain within seconds of inhaling may well have special effects that make cigarette smoking so addictive. Certainly many cigarette smokers who switch to cigars or a pipe continue to inhale ${ }^{1718}$ and do not seem equally satisfied by nicotine absorbed more slowly through the mouth and nose. For such smokers nicotine chewing-gum may have similar limitations.

Conclusions-Plasma nicotine levels obtained from nicotine chewing-gum only approach the levels produced by cigarette smoking when at least 10 pieces of gum containing 4-mg nicotine are taken daily and each is well chewed for about 30 minutes. This dosage of 2-mg gum does not produce an adequate plasma nicotine level. The slower rate of absorption of nicotine from chewing-gum suggests that it would be a closer substitute for non-inhaling cigar or pipe smoking. Its clinical efficacy as an aid to cigarette withdrawal may well depend on the extent to which the smoker smokes to obtain rapid blood nicotine peaks or to maintain a minimum trough level.

We thank A B Leo and Co, Helsingborg, Sweden, for supplying the nicotine chewing-gum, Jean Crutch for secretarial help, Nigel Rawson for checking the statistics; and the Medical Research Council and Department of Health and Social Security for financial support; above all we are indebted to our colleague who was the experimental subject.

\section{References}

${ }^{1}$ Bernstein, D A, and McAlister, A, Addictive Behaviours, 1976, 1, 89.

2 Schwartz, J L, Public Health Reports, 1969, 84, 483.

3 Jarvik, M E, Glick, S D, and Nakamura, R K, Clinical Pharmacology and Therapeutics, 1970, 11, 574.

${ }^{4}$ Russell, M A H, in Research Advances in Alcohol and Drug Problems, vol 3, ed R J Gibbins et al. New York, Wiley and Sons, 1976. 
5 Johnston, L M, Lancet, 1942, 2, 742.

${ }^{6}$ Lucchesi, B R, Schuster, C R, and Emley, G S, Clinical Pharmacology and Therapeutics, 1967, 8, 789.

7 Fernö, O, Lichtneckert, S J A, and Lundgren, C E G, Psychopharmacologia, 1973, 31, 201.

${ }^{8}$ Ohlin, $\mathrm{P}$, and Westling, $\mathrm{H}$, in Second World Conference on Smoking and Health, ed R G Richardson, p 171. London, Pitman, 1972.

9 Brantmark, B, Ohlin, P, and Westling, H, Psychopharmacologia, 1973, 31, 191.

${ }^{10}$ Russell, M A H, et al, in preparation
11 Feyerabend, C, and Russell, $\mathrm{M} \mathrm{A} \mathrm{H}$, in preparation.

12 Feyerabend, C, Levitt, T, and Russell, M A H, Fournal of Pharmacy and Pharmacology, 1975, 27, 434.

${ }^{13}$ Russell, M A H, Cole, P V, and Brown, E, Lancet, 1973, 1, 576.

14 Isaac, P F, and Rand, M J, Nature, 1972, 236, 308.

15 Russell, M A H, et al, Lancet, 1973, 2, 687.

${ }_{16}$ Armitage, A K, Hall, G H, and Sellers, C M, British fournal of Pharmacology, 1969, 35, 152.

17 Cowie, J, Sillet, R W, and Ball, K P, Lancet, 1973, 1, 1033.

18 Castleden, C M, and Cole, P V, Lancet, 1973, 2, 21.

\title{
Combined alpha- and beta-adrenoceptor blockade with labetalol in hypertension
}

\author{
M H FRICK，P PÖRSTI
}

British Medical fournal, 1976, 1, 1046-1048

\section{Summary}

The antihypertensive effect of labetalol, a new alpha- and beta-adrenoceptor inhibiting agent, was studied in 20 patients in a double-blind crossover trial. A dose of $300 \mathrm{mg}$ daily reduced blood pressure only moderately in the supine position, though in the sitting and standing positions the effect was more pronounced. A dose of $600 \mathrm{mg}$ daily produced statistically significant and clinically relevant reductions in blood pressure in all positions studied. The effect on heart rate was small and of significance only in reducing the heart rate increment due to a change in posture. Side effects were mild: only one patient complained of postural dizziness with the higher dose. We conclude that labetalol is useful in the treatment of mild and moderately severe hypertension.

\section{Introduction}

Beta-adrenoceptor blocking drugs hold an established position in the treatment of hypertension, ${ }^{1-6}$ and, though the exact mechanism(s) of blood pressure reduction under long-term treatment with these compounds is unknown, the haemodynamic changes have been well defined. ${ }^{7-9}$ Initially cardiac output is reduced and peripheral resistance variably increased only to return gradually to the pretreatment level. ${ }^{910}$ This initial increase in resistance has been attributed to the unmasked alphareceptor activity in the resistance vessels. A parallel phenomenon in addition to vagal influences is the bronchoconstriction seen in asthmatics due to unopposed alpha-receptor activity in the bronchial wall.

The new salicylamide compound labetalol (5-[1-hydroxy-2(1-methyl-3-phenylpropylamino) ethyl] salicylamide) has been shown in animals ${ }^{11} 12$ and $\operatorname{man}^{13}$ to have both alpha- and betaadrenoceptor blocking properties. Thus theoretically it offers advantages over pure beta-adrenoceptor blocking drugs in the treatment of hypertension. We have studied the antihypertensive

First Department of Medicine, University Central Hospital, Helsinki, Finland

M H FRICK, MD, associate professor

Department of Medicine, Hatanpää Hospital, Tampere, Finland P PÖRSTI, MD, senior staff physician effect of labetalol at two different dose levels using placebo control and a double-blind design.

\section{Patients and methods}

Eleven men and nine women aged 25-65 (mean 44) years were studied. All had diastolic blood pressures of over $100 \mathrm{~mm} \mathrm{Hg}$ on repeated measuring. Intravenous pyelograms and serum potassium and urinary catecholamine determinations showed the hypertension to be essential in 17 patients. Chronic pyelonephritis was found in two patients, and one had congenital aplasia of the right kidney. Based on electrocardiograms and chest $x$-ray pictures the hypertension was graded as mild to moderate (WHO grades I and II). Nine patients were untreated; in 10 patients treatment was stopped one to two months before entry to the trial, and one continued with a diuretic throughout.

The study began with an assessment period of one month during which the blood pressure was measured weekly to ascertain the presence of chronic hypertension in the untreated patients and to determine the blood pressure without treatment in the patients previously treated. The patients were then allocated at random to treatment with either placebo or labetalol $100 \mathrm{mg}$ thrice daily for four weeks followed by a crossover to the alternative compound for a further four weeks. The dose was then increased to $200 \mathrm{mg}$ thrice daily and the procedure repeated. Thus each patient received eight weeks of treatment with each compound. Neither the doctors nor the patients were aware of the periods of active treatment.

Blood pressure was measured fortnightly in a standardised fashion using mercury sphygmomanometers with $13-\mathrm{cm}$ cuffs. The point at which the Korotkoff sounds became muffled (phase IV) was taken as the diastolic pressure. Blood pressure and heart rate were measured after resting supine for five minutes, sitting for three minutes, and standing for two minutes. Haemoglobin and white cell count were determined at the end of each four-week period. Questions about side effects were asked at every visit.

Differences in values between the placebo and labetalol treatment periods were analysed by paired comparison and Student's $t$ test. $P$ values less than 0.05 were regarded as significant.

\section{Results}

With $300 \mathrm{mg}$ labetalol daily only small changes were seen in blood pressure while supine (table) and the heart rate was not modified at all. Doubling the dose produced falls of $10 \mathrm{~mm} \mathrm{Hg}$ and $5-9 \mathrm{~mm} \mathrm{Hg}$ in the systolic and diastolic pressures respectively. Heart rate was also significantly reduced.

In the sitting position the blood pressure was already influenced by the starting dose of labetalol (table) with a further reduction after doubling the dose. The reduction in systolic pressure was about $20 \mathrm{~mm} \mathrm{Hg}$ and that of the diastolic pressure $10-15 \mathrm{~mm} \mathrm{Hg}$. The heart rate was also significantly reduced.

In the standing position the blood pressure was greatly reduced by both dose levels of labetalol (table), amounting to over $20 \mathrm{~mm} \mathrm{Hg}$ 